Knowledge contains articles on curious facts in plant distribution, by Mr. W. B. Hemsley, F.R.S. ; waves, by Mr. Vaughan Cornish ; Antarctic exploration, by Mr. W. S. Bruce ; and comets of short period, by Mr. W. E. Plummer. There is also a full-page reproduction of Dr. Roberts' photograph of the nebula near I 5 Monocerotis. We omitted to mention that in the January number, Dr. H. R. Mill had an article on "Geography as a Science in England," in which he pleaded for a more scientific study of geography.

Longman's Magazine has an excellent short article on the Pasteur Institute, by Mrs. Frankland. Mr. H. M. Stanley tells "The Story of the Development of Africa" in the Cenutry. Among the subjects lightly and brightly treated in Chambers's Tournal are left-handedness, by Dr. R. A. Lundie; turpentine farms in Georgia ; Bath brick; new work on the filtration of water ; and flint.knapping. Dr. Andrew Wilson writes on Meduse in the English Illustrated. A description of the fantastic forms taken by lycopodium powder or a semiliquid substance, when placed upon a flexible mem. brane set vibrating by the voice, is given by Margaret $W$. Hughes in Good Words, under the title of "Voice Figures." The article is illustrated by reproductions of some of the beautiful patterns thus produced. An article entitled "The Romance of the Museums," in the Strand Magazine, contains a short description, with illustration, of the Cranborne meteorite, in the British Museum Collection. The same magazine has in it a short story of adventure, founded upon the action of the "Souffleur" at Port Gorey, Sark. The scientific interest of the story lies in the section which is given of the Gouliot Caves, in order to explain how " Souffleurs " are caused.

\section{THE CONSTITUTION OF SCIENTIFIC} SOCIETIES.

SOME cultivators of the sciences occasionally complain that the meetings of scientific bodies are not well attended, and that they read papers to too many empty benches. Moreover, even when they have a scientific audience they allege that very few of those present understand what they have to say. And they speculate on measures to be adopted to remedy this state of affairs.

As the scientific investigator acquires years and experience, he recognises that in the present state of human society he has no right to expect that the situation can be very different. The number of serious cultivators of science in any community is not large, and the number of men engaged in original research in any given field is still smaller. Like the landed aristocracy of the old nations, the producers in each department of science are well scattered over a country, and it is only on national occasions that they gather in any considerable force. The situation as to the audiences who assemble to listen to papers of original value in pure science is therefore not likely to change for some years. In fact, the size of audiences may be set down as inversely as the rationality, and directly as the emotionality of the matter set before them. Such is the present state of the civilised nations of the earth, and it is not peculiar to any one of them.

Most of the large cities of the United States have an "Academy of Sciences," or its equivalent, and it is largely with reference to the prosperity of those bodies that discussions such as we have referred to above is heard. Many of the members want them to be what they call popular, which, in its best sense, means that they wish for large audiences at the meetings. Now, if what we have said above is true, this object cannot be attained unless the academy abandons its real object, the advancement of scientific knowledge by original research. This is the primary object of academies of science in all countries, and if they neglect it, they lose their identity, since the facilities for the distribution of knowledge are everywhere relatively abundant. When the academy of science becomes a distributor of knowledge only, it abandons its important proper function, and becomes comparatively a nonentity. Let us hope that academies of science in America will not follow the course of the academies of music, which are, in Europe, educational and critical, in America, mere theatres.

The measures adopted by academies of science in the United States to make themselves popular and therefore "successful," are often highly amusing. The usual method is to elect some man president who is rich but unknown to science; since, in the minds of some people, money is the source of the sciences and 1 Reprinted from the American Naturalist, December $\mathbf{1} 895$. NO. [ 37 I, VOL. 53$]$ the arts. Men of the same type are also often elected to other responsible positions in these societies for similar reasons. We have watched this mode of attacking the problem for many years, and have never known it to be successful. In the case of the Philadelphia Academy, it did, on one occasion, entail a loss of over $\$ 12,000$ cash capital to the Society. In fact, the reasons why this method should not prove successful are not'far to seek. The only way to make it successful would be to have a bill of sale of the office legally executed, so that the sum agreed on could be collected by process of law in case of failure to produce the "consideration" after the election. This the business world understands, whereas it does not perceive the cash value of original research. In fact, the election of an outsider to rule over them by a body of experts for a supposed financial equivalent, is a proceeding not calculated to excite the respect of a rich man or any other kind of man.

A society is, however, fortunate if it escapes without more serious injury than a financial disappointment. Men not habituated to the ways and means of research frequently apply nostrums which do more harm than good, and bring the society into deserved contempt. Thus in one city the president, who was of the type mentioned, succeeded in incorporating into the society a body of photographers, with the result of simply developing the photographic society. The men by whom the original society was known to the world were locally quite lost sight of. In another city a number of local amateur astronomical clubs were taken into the academy. These consisted of ladies and gentlemen whose devotion to science consisted in viewing the stars in each others pleasant society. Another acadeniy adopted popular lectures as a device for filling empty benches. The selection of the lectures being in the hands of incompetent officers, cranky and ignorant persons, and those who had apparatus to sell, occupied the time of the academy, to the great scandal of the really scientific men of the city.

The appointment of amateurs and unscientific persons to positions in scientific bodies, often has ludicrous results. One academy of science discussed an ancient bone dredged up in salt water. It was perforated with fossæ in series, and it was concluded that it was a mouth bone of a fossil fish. It turned out to be the head of an ancient tooth-brush. An exhibition of foottracks on ancient rocks before the same academy, brought to his feet a dancing-master, who illustrated the formation of the impressions terpsichorean fashion.

Another plan for promoting the prosperity of scientific bodies is to have dinners and social receptions. These methods are always successful in drawing together numbers, and if persons are to be elected members of such societies in proportion to their gastronomic capacities, such a system must be eminently successful. To be serious, however, and to repeat what should be selfevident to every person, this plan tends only to an increase o. non-expert membership, which is really at the bottom of all the evils which have befallen scientific societies. Hence, unless some measures to protect the membership be adopted, this method of "promotion" should be always rejected.

The result, both of our observations and cogitations on this subject, is that the only method by which academies of science can advance themselves in the public esteem, is to continue in their work of original research. If they cannot acquire public confidence in this way, they cannot acquire it at all. There is no short-cut to this so-called "success." As in all other human endeavours to wrest advantage from nature, labour and labour only "omnia vincit." As with the agriculturist, the machinist, or the accumulator of money, devotion to work, and this only, brings the rewards which we seek. The visible products of labour are what men respect, and if the scientific man wishes to inspire the respect of wealth, he must show results, rather than bestow on men of wealth what are to them empty honours

\section{SCHOLARSHIP SCHEMES OF TECHNICAL EDUCATION COMMITTEES.}

$\mathrm{NE}$ of the chief ways in which Technical Education Commit. tees allover the country spend the fundsentrusted to them is in the award of scholarships; and if this branch of their work is wisely organised and carried out, there is no better method of securing the proper education of promising boys and girls. The scholarships awarded can be divided into four classes, namely, those tenable at (I) Technical Schools and Science and Art Schools; (2) Secondary Schools; (3) Universities or institutions of University rank; (4) short courses of instruction. Full information 